\title{
THE CONTRIBUTION OF ELECTRONIC BANKING TO CUSTOMER SATISFACTION: A CASE OF GCB BANK LIMITED -KOFORIDUA
}

\author{
Martin Otu Offei and Kwaku Nuamah-Gyambrah \\ Koforidua Polytechnic, Ghana
}

\begin{abstract}
Internet banking has the potential to provide fast and reliable services to customers for which they are relatively happy. Due to the technological changes taking place all over the world, many institutions, including the banking sector have taken giant steps to move in tandem with these changes. In this light most banks, with GCB Bank, Ghana, not being an exception have introduced electronic banking in order to decongest the banking halls of customers who spend time unending in order to transact business. The purpose of this research was to assess the Contribution of Electronic Banking to Customer Satisfaction at GCB Bank-Koforidua, to this end some objectives were set for the study. These were: To assess the availability of electronic banking facilities at GCB Bank, Koforidua. To assess the knowledge and patronage of internet banking services by customers, to examine the effectiveness of the usage of electronic banking facilities, to examine the problem facing an internet banking in GCB Bank, Koforidua. This is a quantitative study that employed the use of questionnaires as the main tools for data collection. Data was collected from management, staff and customers of GCB Bank, Koforidua Branch. Findings from analysis of data revealed that though there was the existence of internet banking facilities of the bank, respondents of the study were not fully aware of the existence of such facilities. It was also found that the use of internet banking was quite expensive and that though the bank was utilizing the facility, customers were not fully patronizing them. It was concluded that internet banking brings efficiency in the operations of the bank. Finally, the study recommended that all branches of GCB Bank adopt internet banking facilities to help in effective banking operations and transactional purposes. To maximize the operations and potential of the bank management must endeavor to educate the customers about the existence of internet banking facilities since a few customers were aware of the existence of such facilities.
\end{abstract}

KEY WORDS: internet banking, customer satisfaction, contribution, Ghana, ATM Cards, master cards, visa, debit \& credit cards

\section{INTRODUCTION}

People's presence in banking halls in this modern era, is phasing out with the evolution of Information, Communication and Technology (ICT), coupled with electronic products (Acquah, 2006). The preference for faster, convenient technology, advanced, more rewarding banking experience, and a focus on excellent customer service delivery is becoming more imperative. However, customers' attitude and perception to the use of electronic banking are a challenge. The African Banker 3rd quarter 2011 cover story dubbed "Africa's banking technology as a helpful tool in business strategy" states that "Electronic Banking products have turned out to be the 
International Journal of Managing Information Technology (IJMIT) Vol.8, No.1, February 2016

nucleus or central issue of various technologies in banks all over the globe" (Akoh, 2011). GCB Bank, among others, accepted this technology as a new delivery channel for performing various bank transactions. These Electronic Banking services give the customer the opportunity to conduct banking transactions with great peace of mind and at his/her convenience. It also saves time so that other interests can be taken into consideration. These e-banking activities range from balance inquiry, cash withdrawals, Bill payments, fund transfer, electronic payment, and loan applications among others (Agboola, 2006).

GCB has realized a rapid economic growth due to the usage of this technological banking policy ranging from commerce to IT and financial services.

The progressive technological innovation is at the heart of Ghana's banking institutions, bringing financial services to the unbanked and driving ever-stiffer rivalry in the banking industry - from card technology to mobile banking and to management software (Akinci et al., 2004). The use of electronic payment is becoming the order of the day in the banking industry. Electronic payment includes the use of Automated Teller Machine (ATM), VISA PLUS, Debit cards, mobile banking, telephone banking, SMS banking, internet banking and e-zwich services.

To revolutionize customer service delivery by reducing turnaround time to the barest minimum, whiles offering various forms of self-service to internal and external customers, has been an uneasy task in the industry (African Banker, 2013). According to Bauer and Colgan (2001), the emergence of technology is a system that marks electronic banking -e-banking works - buying and selling of banking services over electronic system and through the internet, e-banking has facilitated ATM'S, VISA, SMS alert, internet banking, e-zwich and mobile banking.

\section{Statement of the Problem}

Serving customers faster is imperative and an ultimate choice of the management of a bank its customers. The use of technology and electronic product in the major banks are becoming a common phenomenon, as the use of ATM, VISA CARD and its associated ICT technology is known to promote efficiency and customer satisfaction in diverse ways. Electronic banking is aimed at promoting customer satisfaction and decongesting of banking halls. The management of the GCB Bank at Koforidua has embarked on promoting electronic banking through the use of ATM (Quick Cash) Visa cards and other electronic product to attract its customers on its usage; it is convenient, reliable, fast and safe. This promotion is through one-on-one education and presentation on the importance of the use of electronic product.

However despite this campaign, the banking hall is always full with customers. Also there is not much information as to how customers perceive the functioning of such electronic products introduced by the banks and how it has impacted on customers' patronage of such services (Jayawardhena\&Foley, 2000; Li, 2001).

Despite the introduction of those facilities, the banks have not fully taken advantage of such facilities, though they have also reduced the human resource strength. This has led to overcrowding in the banking halls and the resultant customer dissatisfaction. The financial system around the world has been facing a lot of challenges. Mergers and acquisitions, deregulation, increased competition, changing information systems and technology, and human resources with different skills are just a few 'forces' that are influencing the banking business (Rogers, 2003). 
International Journal of Managing Information Technology (IJMIT) Vol.8, No.1, February 2016

Despite these investments, empirical research studies investigating the impact of these developments, particularly IT investments on customer satisfaction of service delivery with respect to retail banking is far and few.

The ATMs are also saddled with consistent breakdowns and internet services to easily access it is difficult as far as the ordinary customer is concerned. All these have almost negated the introduction of the internet banking services in general. For the above-mentioned reasons, this study is being undertaken to assess the use of internet banking by GCB Bank and its relationship with customer satisfaction.

\section{OBJECTIVE OF THE STUDY}

The general objective of the study is to assess the contribution of electronic banking to customer satisfaction.

The specific objectives are:

1. To assess the availability of internet banking facilities at GCB Bank, Koforidua.

2. To assess the knowledge and patronage of electronic banking products by customers.

3. To examine the effectiveness of the usage of electronic banking facilities.

4. To examine the problem facing electronic banking products at GCB Bank, Koforidua.

\section{RESEARCH QUESTIONS}

1. What types of electronic banking facilities are available at the GCB Bank, Koforidua?

2. Are customers aware of the availability of all these facilities at GCB Bank, Koforidua?

3. How effective are these facilities being put to use to benefit customers at GCB Bank, Koforidua?

4. What are the problems facing electronic banking at GCB Bank, Koforidua

\section{LITERATURE REVIEW}

Entrepreneurs, bookkeeping staff and other endorsed representatives can get to routine banking activities, for example, stores, cleared checks and wired finances rapidly through a electronic banking interface (Rotchanakitumnuai\&Speece, 2003). This simplicity of audit aides guarantee the smooth preparing of every banking transactions exchange once a day, as opposed to sitting tight for month to month articulations. Slips or postponements can be noted and determined rapidly, conceivably before any business effect is felt (Shittu, 2010). Electronic banking prompts profitability picks up. Robotizing routine bill installments, minimizing the need to physically visit the bank and the capacity to function as required as opposed to on keeping money hours may diminish the time included in performing routine managing an account exercises (Polatoglu\&Ekin, 2001; Sathye, 1999). Moreover, online pursuit apparatuses, managing an account activities and different projects can permit staff individuals to research exchanges and purpose saving money issues all alone, without cooperating with bank representatives. At times, month-end compromises for Visa exchanges and financial balances can be mechanized by utilizing electronic banking records. Saving money connections and expenses are regularly taking into account asset necessities (Steven 2002; Thornton \& White, 2001). Organizations that place more requests on saving money workers and need more physical help with wire exchanges, 
stores, exploration solicitations and other managing an account exercises regularly bring about higher saving money charges. Deciding on electronic banking minimizes business overhead and managing an account costs.

As indicated by Robinson (2000) using e-saving money diminishes keeping money mistakes. Automation of payments, wires or other predictable money related exercises guarantees installments are set aside a few minutes and may counteract blunders created by console slips or client mistake. Also, deciding on electronic managing an account dispenses with blunders because of poor penmanship or mixed up data (Grouchy, 2002; Mols, 1999). Much of the time, electronic documents and every day audits of managing an account information can be utilized to twofold or triple check key bookkeeping information, which expands the exactness of money related explanations. Expanded examination of corporate funds through reviews and hostile to misrepresentation measures obliges an abnormal state of perceivability for every single money related exchange (Hughes, 2001). Depending on electronic banking gives an electronic foot shaped impression to all bookkeeping work force, directors and entrepreneurs who change managing an account exercises. Electronic banking offers perceivability into keeping money exercises, which makes it harder for under-the-table or deceitful exercises to go on (Moutinho\& Meidan,1989).

The Banking industry in Ghana assumes a critical part in the nation's economy. Through getting, loaning and related exercises, banks encourage the procedure of creation, appropriation, trade and utilization of riches. Banks additionally direct installment frameworks which are centre to an economy. Rivalry and constraint of assets has put banks under weight to bring down their valuebased cost and enhance their administrations and keep up nature of administration. As indicated by Yasuharu (2003), execution of data innovation and correspondence systems administration has realized an upheaval in the working of the banks and the budgetary establishments. The move to electronic managing an account has subsequently turned into a need for banks as it offers significant open doors as far as upper hand and it additionally permits banks to build up a more grounded and more sturdy business association with its clients.

As indicated by Wisdom (2012) the quick changes in business operations in contemporary times as innovative change oblige banks in Ghana to serve their clients electronically. Customarily, banks have been in the cutting edge of saddling innovation to enhance their items and administrations. The keeping money industry and its surroundings in the 21 st century is exceptionally perplexing and focused and in this way the requirement for data and correspondence innovation to take focal point of the audience in the operations of banks (Stevens, 2002).The approach of current innovation, for example, web utilization is growing quick and is continually conveying new measurements to our day by day life. The saving money industry is one of the areas that has profited from the advancing innovation by the presentation of Electronic managing an account (Electronic banking) frameworks which give simple access to saving money administrations. The study was done to evaluate the prospect and difficulties of Electronic banking in SG-SSB LTD in Accra, Ghana. Ninety (90) organized surveys were regulated to clients of Electronic banking items and some keeping money staffs to accumulate data concerning E-saving money. 
International Journal of Managing Information Technology (IJMIT) Vol.8, No.1, February 2016

\section{RESEARCH METHODOLOGY}

This was a cross sectional study conducted at Ghana Commercial Bank Ltd. - Koforidua Branch.Fraenkel and Wallen (2003) are of the perspective that, testing is the procedure by which a portion is chosen to speak to the aggregate populace in general. The procedure of testing makes it conceivable to draw inductions through watchful perception of variables inside of little extents of the populace. In testing, the principle target is to choose a segment of the universe. An example in an examination study alludes to any gathering from which data is acquired. The bigger gathering to which one plans to apply the outcomes is known as the populace.

Due to the scattered and heterogonous nature of the respondents, the researcher adopted, the convenient sampling technique to sample customers of the bank for the questionnaire administration and the staffs were also purposively interviewed to augment the information and data. This is because it was not easy for the researcher to obtain records of the customers from the Bank hence there was no sampling frame to assist in the distribution of the questionnaire. However to avoid duplication and multiple sampling any customers given questionnaire was given a code with the day, date and time marked on it.

As indicated by Twumasi (2001) there are two sorts of inspecting procedures utilized as a part of different examination studies. These are likelihood and non-likelihood testing. He further calls attention to that in likelihood testing, every single unit inside of the populace is given equivalent shot of being chosen. In the determination of the example estimate, a staff rundown of the considerable number of classifications was acquired and staffs were chosen arbitrarily and the surveys served to them. Individuals from the administration group, some senior authorities and Human Asset chiefs were, on the other hand, purposively chose for talking.

Therefore, basic arbitrary inspecting (likelihood strategy) and reason examining (a non-likelihood testing system) were the principle routines utilized as a part of selecting the respondents. The sample size was 100, made up of 3 Management members, 14 employees and 83 customers. Systematic sampling procedure was employed to select respondents from among the customers. Due to the limited number of staff of the GCB Bank, Koforidua branch, purposive sampling method was employed to select the participants i.e. management and staff.

- All the staff of the Koforidua Branch of the Bank was included in the study to allow for adequate representation of the various views expressed.

- Systematic sampling selection method was used. A total of 110 questionnairewere administered to 110 customers and out of that 100 responded, representing $91 \%$, filled and returned their questionnaire.

\section{FINDINGS AND DISCUSSIONS}

\subsection{SOCIO-DEMOGRAPHIC CHARACTERISTICS OF RESPONDENTS}

Table 1: Gender Distribution of Respondents

\begin{tabular}{|l|l|l|}
\hline Gender & Number & Percentage \% \\
\hline Male & 55 & 55 \\
\hline Female & 45 & 45 \\
\hline Total & $\mathbf{1 0 0}$ & $\mathbf{1 0 0}$ \\
\hline
\end{tabular}

Source: From Survey Data, 2015 
Results in table 1 indicates that majority of the respondents (55\%) are males. The remaining $45 \%$ are females. This implies that, all things being equal, there are more male customers of the bank than female customers.

Table 2: Educational background of respondents

\begin{tabular}{|l|l|l|}
\hline Educational background & Number & Percentage (\%) \\
\hline SHS/Secondary & 10 & 10 \\
\hline Voc/Commercial/Technical & 8 & 8 \\
\hline Diploma & 28 & 28 \\
\hline Bachelors' & 33 & 33 \\
\hline Masters' & 6 & 6 \\
\hline Others (Specify) & 15 & 15 \\
\hline TOTAL & $\mathbf{1 0 0}$ & $\mathbf{1 0 0}$ \\
\hline
\end{tabular}

Source: from Survey Data, 2015

It can be seen from Table 2 that almost all the respondents who were involved in this study had some form of education. Majority of them (67\%) had higher education, this covered qualifications from diploma to master's degree, with only a few (33\%) having lower qualifications. This is an indication that the respondents are highly educated. This also adds a lot of credibility to the data/information provided since they would be able to read and interpret the questionnaire. This ability to understand is an important factor in the successful administration of questionnaires for any research work.

\section{FURTher AnAlysis}

Table 3: Accessibility of internet banking facilities

\begin{tabular}{|l|l|l|}
\hline Availability of facility & Number & Percentage (\%) \\
\hline YES & 90 & 90 \\
\hline NO & 10 & 10 \\
\hline TOTAL & $\mathbf{1 0 0}$ & $\mathbf{1 0 0}$ \\
\hline
\end{tabular}

Source: from Survey Data, 2015

Table 3 provides information relating the availability of internet banking facilities at GCB Bank, Koforidua Branch. It can be seen from the table that almost all the respondents (90\%) who were involved in this study confirmed the existence and availability of internet banking facilities at GCB Bank. However, only a few of the respondents (10\%) were of the opinion that such facilities do not exist. It is important that management of the branch make conscious efforts to educate all their customers about the existence of such facilities for good banking. 
International Journal of Managing Information Technology (IJMIT) Vol.8, No.1, February 2016

Table 4: Knowledge of Internet Banking by Respondents

\begin{tabular}{|l|l|l|l|l|l|l|l|}
\hline SMS: & $\begin{array}{l}\text { Mobile } \\
\text { banking }\end{array}$ & ATM & Visa & Master & Debit \& credit & Total & $\begin{array}{l}\text { Percentage } \\
(\%)\end{array}$ \\
\hline $\begin{array}{l}\text { Mobile } \\
\text { banking }\end{array}$ & 0 & 20 & 5 & 3 & 0 & 28 & 28 \\
\hline Cards: & & & & & & & \\
\hline ATM & 20 & & 18 & 1 & 1 & 40 & 40 \\
\hline Visa & 5 & 8 & & 3 & 2 & 18 & 18 \\
\hline Master & 1 & 1 & 3 & & 4 & 9 & 9 \\
\hline Debit \& credit & 0 & 1 & 1 & 3 & 0 & 5 & 5 \\
\hline Total & $\mathbf{2 6}$ & $\mathbf{3 0}$ & $\mathbf{2 7}$ & $\mathbf{1 0}$ & $\mathbf{7}$ & $\mathbf{1 0 0}$ & $\mathbf{1 0 0}$ \\
\hline
\end{tabular}

Source: from Survey Data, 2015

Table 4 is a square matrix (5x5) table displaying respondents' knowledge of internet banking at the GCB Bank, Koforidua branch, with regard to Mobile banking, ATM, VISA, MASTER Cards, as well as, Debit and Credit cards. From the banking data, the summarized statistics indicate that the respondents are more informed on ATM and MOBILE BANKING, representing 28\% and $40 \%$ respectively. However, with regard to internet banking via VISA, MASTER AND DEBIT \& CREDIT CARD, it came out that respondents have limited knowledge on them,(having 18\%, 9\% and 5\%) respectively. It can be deduced for the statistics that customers are using different kinds of technology-based products, either singularly or in multiples. This is an indication of the customers' receptive response to the introduction of such products in the banking sector. Further analysis and results on knowledge of internet availability in terms of some central tendencies are displayed in the Table 5.

Table 5: Central Tendencies of Knowledge of Internet Banking

\begin{tabular}{|c|c|c|c|c|c|c|c|}
\hline $\begin{array}{l}\text { Central } \\
\text { tendency }\end{array}$ & Column 1 & Column 2 & Column 3 & Column 4 & Column 5 & Column 6 & Column 7 \\
\hline Mean & 6.5 & 7.5 & 6.75 & 2.5 & 1.75 & 20 & 0.2 \\
\hline $\begin{array}{l}\text { Standard } \\
\text { Error }\end{array}$ & 4.6278145 & 4.481443 & 3.8378596 & 0.5 & 0.8539126 & 6.3796552 & 0.063796552 \\
\hline Median & 3 & 4.5 & 4 & 3 & 1.5 & 18 & 0.18 \\
\hline Mode & \#N/A & 1 & \#N/A & 3 & \#N/A & \#N/A & \#N/A \\
\hline $\begin{array}{l}\text { Standard } \\
\text { Deviation }\end{array}$ & 9.2556289 & 8.962886 & 7.6757193 & 1 & 1.7078251 & 14.265343 & 0.142653426 \\
\hline Range & 20 & 19 & 17 & 2 & 4 & 35 & 0.35 \\
\hline Minimum & 0 & 1 & 1 & 1 & 0 & 5 & 0.05 \\
\hline Maximum & 20 & 20 & 18 & 3 & 4 & 40 & 0.4 \\
\hline Sum & 26 & 30 & 27 & 10 & 7 & 100 & 1 \\
\hline Count & 4 & 4 & 4 & 4 & 4 & 5 & 5 \\
\hline Large & 20 & 20 & 18 & 3 & 4 & 40 & 0.4 \\
\hline Small & 0 & 1 & 1 & 1 & 0 & 5 & 0.05 \\
\hline
\end{tabular}

Table 5 reports the central tendencies (mean, standard error, median, mode, standard deviation, variance, etc.), with regard to knowledge in availability of internet banking specifically Mobile banking, ATM, VISA, MASTER Cards, and Debit and Credit cards. The mode is not applicable 
in this study as most of the columns did not have means hence the display value N/A. The means show between the largest and the smallest observation that the average number of respondents have knowledge of availability of internet banking at the facility, of course with minimal errors.

Table 6: Importance (uses and purpose) of Internet Banking

\begin{tabular}{|l|l|l|}
\hline Uses/Purpose & Number & Percentage (\%) \\
\hline Checking account balance and mini statements & 35 & 35 \\
\hline Quick access to money & 42 & 42 \\
\hline Inter banking & 18 & 18 \\
\hline International transaction & 5 & 5 \\
\hline TOTAL & $\mathbf{1 0 0}$ & $\mathbf{1 0 0}$ \\
\hline
\end{tabular}

Source: from Survey Data, 2015

Having established the fact that there is existence of internet banking and the various forms of facilities, it was appropriate to find out the specific importance of the facilities and uses by respondents. The results from the Table 6 shows that there are four main uses of internet banking facilities as given by the respondents who were involved in this study. Thirty five out of a total of 100 respondents who were involved in this study used it for checking account balance and statements, 42 representing $(42 \%)$ on the other hand used it for withdrawal purposes, 18 respondents which represents $(18 \%)$ used it for inter banking and the remaining 5 respondents used it for international transactions.

Table 7: Effectiveness of the Usage of Internet Banking Facilities by Respondents

\begin{tabular}{|l|l|l|}
\hline Effectiveness of facility & Number & Percentage(\%) \\
\hline Strongly agree & 55 & 55 \\
\hline Agree & 40 & 40 \\
\hline Strongly disagree & 0 & 0 \\
\hline Disagree & 3 & 3 \\
\hline No response & 2 & 2 \\
\hline Total & $\mathbf{1 0 0}$ & $\mathbf{1 0 0}$ \\
\hline
\end{tabular}

Source: from Survey Data, 2015

From table 4.3.8 above, majority of the respondents (55\%) agree strongly that the internet banking facilities provided by the bank are very effective. Only a small minority (3\%) disagree with that. The remaining $2 \%$ could not even decide. This implies that customers generally accept the fact that the use of internet facilities by the bank had a wide acceptability among its customers.

Table 8: Problems Associated with Internet Banking

\begin{tabular}{|l|l|l|}
\hline Problems in internet banking & Number & Percentage (\%) \\
\hline High cost in maintaining internet banking & 10 & 10 \\
\hline High cost in getting reliable internet connectivity & 7 & 7 \\
\hline High cost of internet charges & 83 & 83 \\
\hline Total & $\mathbf{1 0 0}$ & $\mathbf{1 0 0}$ \\
\hline
\end{tabular}

Source: from Survey Data, 2015 
International Journal of Managing Information Technology (IJMIT) Vol.8, No.1, February 2016

With regard to problems associated with internet banking, result in table 8 indicate that the major challenge given by the respondents was that of high cost of internet service charges, representing $83 \%$. This was followed by high cost of maintaining internet facility and high cost of getting reliable internet connectivity, representing $10 \%$ and $7 \%$, respectively. The high charges could be attributed to those responses given by the customer respondents, whilst the remaining $17 \%$ of cost of internet maintenance and reliable service could be attributed to management and employees of the facility.

The implication of this finding is that customers are weary of the high cost of transacting business using internet banking services. This situation, if not dealt with by the bank could have negative consequences, as customers may revert to the old system of doing business with the bank. Furthermore, the unreliable nature of internet services in general is a great disincentive to the use of internet banking, as customers are not likely to be able to transact business at their own convenience.

\section{FINDINGS, CONCLUSIONS AND RECOMMENDATIONS}

The use of internet in business in the 21 st century is a very important and powerful tool that cannot be over emphasized. As a result most banks have adopted its use through systems that are efficient to maximize business potentials and objectives. This study sought to assess the level of adoption of internet banking and its relationship with consumer acceptance, using GCB Bank, Koforidua as a case study.

The following are the findings of the study on the basis of the analysis that have been performed: Firstly, the study revealed that there is availability of internet banking services at GCB Bank for use by customers. However, a few of the respondents (customers) were not aware of such facilities. Specifically, those internet facilities that were available for use ranged from availability and use of ATM, MOBILE BANKING services, VISA, MASTER AND DEBIT \& CREDIT CARD.

Secondly, it came out that there were four main uses of internet banking facilities as given by the respondents which include checking account balance and statements, withdrawal purposes, inter banking and international transactions. Some of these uses could be performed at one's convenience, either at home, office or at any place.

The study also found out that internet banking facilities existing at the branch were very effective in their operations. There are however, some few challenges with their use by customers.

The main challenges are that of both management and customers. Management were of the view that internet banking facilities were quite expensive in their operations and maintenance, whilst customers on the other hand were of the opinion that internet banking service charges were quite expensive.

Taking into account the discoveries of the study, the accompanying conclusions were come to: Firstly, availability of internet banking facilities is important for performing all bank transactions especially at ones' own comfort.

Secondly, internet banking facilities come with extra operational cost and of course corresponding charges that are usually meted out to customers or users of such facilities. 
Furthermore, availability of internet banking facilities make bank operations and transactions very effective to management, employees and customers as well.

Finally, it can be concluded that on the overall, internet banking adopted by GCB Bank Koforidua Branch is very well accepted and used by the customers of the Bank for various bank transactions and purposes.

In light of the discoveries and conclusions got from the study, the accompanying suggestions are made:

It is recommended that all branches of GCB Bank adopt efficient internet banking facilities to help in effective banking operations and transactional purposes. The efficiency and effectiveness of its services is a determining factor that influence customer satisfaction.

Internet transaction cost should be re-examined by management since it was the main challenge to customers with regard to internet banking. This is because the high cost has the tendency to scare prospective customers.

- Management of GCB Bank must endeavour to educate the customers about the existence of internet banking facilities since only a few customers were aware of the existence of such facilities. This would help to maximize the operations and potential of the bank.

- It is further recommended that management of the bank should take steps to address the problem of constant breakdown of ATMs and the rampant manner in which the ATM machines capture customers' cards. These problems have a negative effect on the mindset of customers. When they are addressed, it will go a long way to build and instill confidence in customers.

\section{BIODATA AND CONTACT ADDRESSES OF AUTHORS}

Martin Otu Offei is a lecturer at the Computer Science Department and currently the Director of the ICT Directorate at the Koforidua Polytechnic. He holds a Bsc and Msc degree in Computer Science.

Martin Otu Offei

Koforidua Polytechnic, Ghana

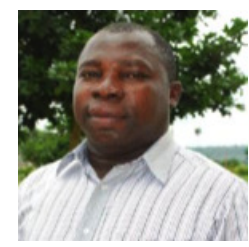

Kwaku Nuamah-Gyambrah is a Lecturer in the Computer Science Department of Koforidua Polytechnic with over 10 years' experience in teaching and research. He holds an MSc in Software Technology with Network Management.

Kwaku Nuamah-Gyambrah

Koforidua Polytechnic, Ghana

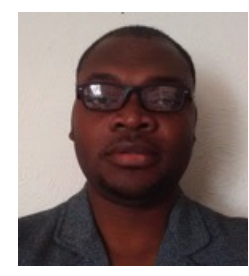

\section{REFERENCES}

[1] Acquah, P.A. (2006). Evaluating the Banking System in Ghana. Accra: Fifth Banking Awards Ceremony

[2] Agboola, A.A. (2006). Electronic Payment Systems and Tele banking Services in Nigeria.Journal of Internet Banking and Commerce, 11.

[3] Akinci, S., Aksoy, S. and Atilgan E. (2004).Adoption of Internet Banking among Sophisticated Consumer Segments in an Advanced Developing Country.International Journal of Bank Marketing, Vol. 22 No. 3, pp. 212-232 
International Journal of Managing Information Technology (IJMIT) Vol.8, No.1, February 2016

[4] Akoh, B. (2001). E-Business in the Developing World, Africa and Ethiopia.In Conference on Information and Communication Technology and Development.

[5] Babin, B. J., Carr, J. C., and Griffin, M. (2010).Business Research Methods. 8th Edition. SouthWesternCengage Learning.

[6] Bauer, C., \&Colgan, J. (2001). Planning for electronic commerce strategy: an explanatory study from the financial services sector. Logistics Information Management, 14(1/2), 24-32.

[7] Fraenkel, J. R., Wallen, N. E., \& Hyun, H. H. (1993). How to design and evaluate research in education (Vol. 7). New York: McGraw-Hill.

[8] Gurau, C. (2002). E-banking in transition economies: The case of Romania. Journal of Financial Services Marketing, 6(4), 362-378.

[9] Haque, A. K. M., Ismail, A. Z., \&Daraz, A. H. (2009). Issues of e-banking transaction: an empirical investigation on Malaysian customers perception. Journal of applied Sciences, 9(10), 1870-1879.

[10] Hughes, T. (2001). Market Orientation and the Response of UKFinancial Services Companies to Changes in Market Condition as a Result of E-Commerce.International Journal of bank marketing, 19 (6), $222-231$.

[11] Jayawardhena, C., \& Foley (2000). Changes In The Banking Sector - The Case of Internet Banking in the UK, Internet Research: Electronic Networking Applications and Policy, Vol. 10, No. 1, pp. 19-30.

[12] Li, F. (2001). The Internet and the Deconstruction of the Integrated Banking Model,British Journal of Management, Vol. 12, pp. 307-22.

[13] Mols, N. P. (1999) The Internet and the Banks' Strategic Distribution Channel Decisions, International Journal of Bank Marketing, 17 (6), pp.245-300.

[14] Moutinho, L., \&Meidan, A. (1989). Bank Customers' Perceptions, Innovations and New Technology, International Journal of Bank Marketing, Volume 7 No. 2, pp. 22-27.

[15] Polatoglu, V. N. andEkin, S. (2001).An Empirical Investigation of the Turkish Consumers' Acceptance of Internet Banking Services.International Journal of Bank Marketing, 19(4), 156-165.

[16] Robinson, G. (2000). Bank to the future. Internet Magazine.

[17] Rogers, E. (2003).Diffusion of Innovations, 5th edn Free Press. New York.

[18] Rotchanakitumnuai, S., \&Speece, M (2003). Barriers to Internet Banking Adoption: a qualitative study among corporate customers in Thailand.International Journal of Bank Marketing, vol. 21, no.6/7, pp. 321-23.

[19] Sathye, M. (1999). Adoption of Internet Banking by Australian Consumers: An empirical investigation, International Journal of Bank Marketing, Vol. 17 No. 7, pp. 324-34.

[20] Shittu, O. L. O. R. U. N. S. E. G. U. N., \& FULFILMENT, I. P. (2010). The Impact Of Electronic Banking In Nigeria Banking System (Critical Appraisal Of Unity Bank (PLC). LadokeAkintola University of Technology, Ogbomoso.

[21] Steven, A. (2002). Information systems: The Foundation of E-Business. New Jersey: Anderson, 1136.

[22] Thornton, J., \& White, L., .(2001) Customer Orientations and Usage of Financial Distribution Channels, International Journal of Bank Marketing, Volume 15 No. 3, pp. 168-185.

[23] Turban, E., Lee, J., King, D., Chung, M., (2000) Electronic Commerce: A Managerial Perspective, Prentice Hall International, Inc:New Jersey.

[24] Twumasi, P. A. (2001). Social Research in Rural Communities, 2nd Ed. Accra: Ghana Universities Press.

[25] Wisdom, K (2012).The Impact of Electronic Banking on Service Delivery to Customers of Ghana Commercial Bank Limited.A Study of Ghana Commercial Bank Ltd. Ho Polytechnic Branch.

[26]Yasuharu, U. (2003).The Effects of Information System Investment in Banking Industry. 